\title{
Analysis on the Loss of Farmers' Rights and Interests during the Agricultural Land Transfer in the New Era
}

\author{
Yang Bin ${ }^{1,2}$, Wang $\mathrm{Li}^{2}$ \\ ${ }^{1}$ Southwest Jiaotong University, Chengdu, Sichuan, 611756 \\ ${ }^{2}$ China West Normal University, Nanchong, Sichuan, 637009
}

Keywords: Farmland Circulation, Farmers' Rights, Interest

\begin{abstract}
In China, land has always been the basic means of production of farmers. Because the survival and development of farmers are all linked with the ownership of land and the possession of land, farmers' rights and interests are attached to the land. The problem of the relationship between farmers and land relates to the grand blueprint of building a socialist society. The steady transfer of rural land is an important way to increase the income of farmers. As a new thing in rural land transfer, some problems inevitably arise in the actual operation of rural land. To a certain extent, this has caused harm to the rights and interests of farmers.
\end{abstract}

\section{Introduction}

On the basis of household contract management, the two-tier management system that combines unification, is our country rural basic management system, is the foundation of the party's rural policy [1].The basic management system suitable for China's national conditions, it is suitable for the characteristics of agricultural production, in line with the hundreds of millions of farmers will, must unswervingly adhere to the basic management system, and continuously improve in practice. Stabilize and improve the basic rural operation system, involving three important theoretical knowledge and policy issues [2].

\section{The Legitimate Rights and Interests of Farmers Can Not Be Respected}

\subsection{The farmers' production and operation autonomy are interfered}

Farmers are the dominant position in the circulation of land and have the right to transfer land voluntarily according to law. Township and village organizations can only provide intermediary and information services for the transfer of land. However, in some areas, the rural and village organizations regard land transfer as an increase Some township governments intervened in their own efforts to arrange production and operation projects, forcibly reclaimed contracted land for migrant workers and forced farmers to purchase the designated means of production or sell the agricultural products according to the designated channels, rigidly adjust the farmer contracted land with the method of administrative order, use the power to change or terminate the land contract, and force farmers to transfer land. Because the farmers themselves only have the power of contracting management, the village collective organizations that are the spokespersons of ownership are naturally the plenipotentiaries. The farmers' lack of negotiation status and their ability to defend their own interests are also weak, resulting in loss of rights [3].

\subsection{The lack of rights of information, participation, supervision}

Because the mechanism of democratic council in rural areas is not perfect, farmers' rights to know and transfer of land are often represented by "rural cadres", the transfer of farmland is not transparent, the financial affairs are not open and the villagers cannot exercise their supervisory power. As a result, interception, embezzlement, private sub-phenomenon happened frequently. Since farmers were excluded from the negotiation, farmers did not understand the information such as transaction price and land use time. This created the conditions for some leaders to take the 
opportunity to intercept interests. It is because of the interest in circulation that many collective organizations are willing to transfer land. In the recent investigation of village cadres suspected of economic violations, many cases occurred in the land transfer process. Village cadres in the land, land leasing, demolition and resettlement and other collective capital allocation discretion is too large, but also because of the lack of effective supervision, resulting in a large number of funds flowing into the pockets of rural cadres, farmers land contractual management of the main body of the absence of circulation, the farmer's autonomous decision-making power is deprived of administrative power. Farmers are the mainstay of land transfer. Village-level organizations can only guide and regulate on the basis of respecting the wishes of farmers. However, in practical work, village-level organizations often turn their backs on behalf of others and the result can only be counterproductive. At present, "control of land transfer is mainly concentrated in the hands of township and village-level cadres, and land transfer often loses its due efficiency and fairness. In the name of scale management and agricultural restructuring, it forcibly advances the transfer of land and forcibly rent land at a low price [1].

\subsection{Land is being changed for agricultural use, and the legitimate rights and interests of farmers lack effective protection}

The township government is eager to attract foreign investment and sign the land charter contract with the enterprise without the consent of the peasant household. There are also some villages and communities that arbitrarily terminate the contract in the name of the collective and force the farmers to transfer or lease the land so that the contractual management of the peasant household's land can be invisible deprived of grassroots government. Some foreign enterprises develop and lease farmers 'land. For the expectation of their own economic interests, most of the compensation for farmers' and collective-owned land has been paid once a year. However, due to the natural and market risks of agriculture, enterprises in the event of a business failure, in many cases, it flies away without fulfilling contractual obligations and can not meet the contractual and compensation costs for the farmers [2]. And in many places, the price of land is too low when the land is leased and leased, and the contract period is too long. Although the farmers have immediate benefits, in the long run, the rent of farmers' land has been maintained in the long run This will inevitably affect the long-term interests of farmers. Even some enterprises, after becoming a piece of leased land, have illegally built permanently fixed structures on cultivated land. Some even simply rent land for cultivation and set up factories, which have fundamentally changed the agricultural use of land. This will inevitably affect the interests of farmers.

\section{Land Transfer Procedures Are Not Standardized}

The Land Contract Law of the People's Republic of China stipulates that the transfer of land should be handled by more than two thirds of villagers' committees or over two thirds of villager representatives in accordance with the law in accordance with the law. Local people's governments at or above the county level shall handle the land contracting Management of warrants, and registration of the record, to determine the land contractual management rights. However, in many parts of the actual operation process, they did not follow these procedures, resulting in these procedures are just forms, resulting in the main body of the land transfer operation in the process of circulation, mainly in: Some land transfer in the process of circulation, did not pass any written contract, based on verbal agreements alone, has laid down hidden dangers for future disputes. Some farmers have not submitted written applications to their respective collective economic organizations in advance and circulated privately, nor have they reported to the collective economic organizations after land transfer, which is not favorable the protection of their own rights and interests also disrupts the management order of local governments on the land. Many land transfer

contracts are not standardized. For example, some contracts contain many loopholes and the rights and obligations stipulated by both parties are not clear enough [2]. Many land transfer contracts are not standardized local governments did not sign the contract of transfer of land without the written authorization of the farmers, resulting in inefficiencies in the contract. Some contracts did not go 
through the registration formalities in accordance with relevant regulations. Due to the non-standard operating practices, the disorder of the market operation of the land transfer market is caused. This also causes the local governments, especially the township and town cadres, to use their administrative power to misappropriate and abuse the land by means of circulation. Coupled with the lower cultural and legal level of farmers, Land transfer process, often in a disadvantaged position, the final rights and interests damaged farmers' rights.

The non-standard operation of land transfer and farmers 'interests are infringed upon: "First, on the land contract, some grassroots cadres relied on the identity of the landowner's representatives to force the circulation of land by the administration and seriously damage the rights and interests of the farmers' land. On the formalities of circulation, farmer households that collective and land circulation did not sign normative contracts or agreements, and some did so on the verbal promises made by village cadres alone, resulting in many disputes. Third, during the circulation process, some places were under contract and the collective economy the organization did not openly invite public bidding and outsourcing in accordance with the regulations, and some village cadres reached deals with the renters in private and deceived the masses. "[2]

\section{Grass-roots Administrative Organizations Are Improper}

In the process of land transfer, village committees tend to act on behalf of local governments instead of representing the interests of collectives, causing the township people's government to swept away administrative things in rural areas for a long time, depriving farmers of their own choices and undermining farmers' interests.

\subsection{With all sorts of excuses, deprivation of decision-making power of farmers}

According to the Land Administration Law, "collectively-owned land owned by farmers belongs to the collective ownership of farmers by the village and operated and managed by village collective economic organizations or villagers 'committees. Therefore, the implementation of the management of land by the committees may lead to the grass-roots administrative organizations' Farmers' Legal Rights and Interests Infringement "[3]. In many places, local governments resorted to administrative means to make rigid circulation. Relevant information was introduced. In order to force peasant households to transfer land, some local governments dispatched many police cars and used violence tools such as electric batons and handcuffs to confront their farmers. Some local governments under the pretext of "large-scale management", "special agriculture" and "narrow land and modern production incompatibility", it is necessary to force farmers to lease land for long periods of time to industrial and commercial enterprises. This practice also deprives farmers of their autonomous decision-making power. These The act seriously infringed upon the legitimate rights and interests of farmers.

\subsection{Grassroots cadres use their resources to cheat farmers and compete for profits with the people}

In recent years, in the process of land transfer, grassroots governments cheat farmers by means of administrative means and frequently compete for profits with the people. Some local governments forced to "rent" farmer land at low prices and then sublet them to other land transfer entities at high prices, thus depriving them of part of their land revenue. This is done in the form of "anti-renting and releasing" forms. Local governments rely on the hands which is a common way for the grassroots governments to "borrow money from land" by facilitating the daily living of resources, using the disadvantaged status of farmers in information, engaging in the operation of secret agents, deceiving farmers and winning profits with the people.

\section{Income Distribution in the Land Transfer Unreasonable}

In terms of the rent and leasing period of land transfer, the expected space for the growth of farmers' income and the possible payment crisis of enterprises are not fully estimated, and the rent 
paid to farmers is too small. In recent years, with the adjustment of industrial structure, the income of land contract has obviously increased. However, the compensation for the transfer of land for farmers has not been raised correspondingly. Even some villages do not transfer the proceeds from transfer to farmers and retain the peasant compensation. At present, many of the compensation for land transfer income have not been scientifically assessed on the value of the land, but based on the proceeds from the cultivation of crops as the base, giving due consideration to the interests of farmers and not considering the land appreciation after the transfer. Due to the unclear land tenure, there is no standard for what the parties should receive. In the long run, the benefits of farmers' contractual transfer of land must be reflected in land rents, with a substantial increase in revenue and a reasonable distribution among landowners and users. However, many grassroots cadres in the countryside mistakenly believe that the proceeds of land transfer should be owned collectively and have greatly damaged the interests of farmers. Because farmers are in a weak position in grasping the information of land transfer and can not fully grasp the market conditions of land transfer, farmers have not closely linked the land to be circulated with the market factors such as the location of the land, the supply and demand of land, the pricing is arbitrary, leading farmers not to share the added value of land. Many local governments intervened in the process of land transfer by administrative means, combining administrative power with commercial interests, forcing farmers to transfer land at low prices and at low rent, which seriously infringed the interests of farmers. Many things cause the formation of the market price of farmland usufruct circulation in our country is artificially distorted, and the price of farmland usufruct transfer is much lower than its due price.

\section{After the transfer of land for agricultural practitioners have some violations}

\subsection{The levels of farmers' employment have declined to a certain extent}

On the one hand, the employment channels manifested in farmers are relatively narrow. After the transfer of land, due to cultural, technical and other factors, many farmers have experienced employment difficulties after the transfer of land. On the other hand, farmers have lower employment levels. Even though some farmers have achieved employment, their employment levels are relatively low. After the transfer of land, most of the farmers are engaged in relatively simple and simple jobs, and they are not competent for skilled and complicated jobs.

\subsection{The cycle of land transfer is too long, hampering the interests of farmers}

In the one-time long-term circulation of land, the market-based profit of land is constantly changing due to changes in the supply and demand of land and the development of social productive forces, so that there is a lack of relationship between the ever-changing market-based profit of land and the income of farmers. The combination of points, if the farmers run out of income, it is possible life lost support.

\subsection{Improper guidance and resettlement of farmers is after the transfer of land}

Large-scale, long-term centralized management of land will lead to the emergence of land-expropriated peasant groups. Some of these people are non-diplomats and unskilled. If not properly handled, they are likely to become migrant urban residents and cause a series of social problems. The impact of the process of building a harmonious society in China, thus violating our original intention of the transfer of land.

\section{Conclusions}

Land is the most important agricultural production factors, is also very big the interests of the farmers is the most important implementation conditions and carrier.To ensure that the rural land circulation of peasant rights and interests of intact, give full play to their enthusiasm, will promote the rapid development of China's agricultural production. 


\section{Acknowledgements}

This article is a staged achievement of the 2017 Ministry of Education Youth Fund Project "Study on the Plight of Grassroots Governance and Innovation Strategy Caused by Floating Population in Rural Areas under the Separation of Sanctions" (Item No. 17YJC810019).

\section{References}

[1] Ma Ruping, Sun Fang, "Protection of Farmers' Rights and Interests in the Circulation of Land Contractual Management Right", Agricultural Economics, No.4, 2013, pp. 45-47.

[2] Dai Qinglan, "Rights and Interests of Farmers in the Transfer of Rural Land Use Rights," Journal of Heilongjiang Institute of Education, 2016, No. 2, pp. 34-36.

[3] Wanjun, "bondage of farmland property rights system", Economic Observer, 2014, 5-11. 